\title{
Ética e moral na Contemporaneidade
}

Dejalma Cremonese*

Resumo: Este artigo trata sobre a dimensão da ética e da moral na contemporaneidade. Por ética entendemos princípios, valores, hábitos e costumes que foram criados pelo homem para que pudesse viver em sociedade. Por outro lado, a moral está ligada a ações mais particulares, permeada de um forte apelo religioso. Veremos que a ética é sempre relativa e muda de acordo com o tempo, o espaço e a cultura. O que pode ser antiético para uma comunidade pode ser bem-aceito para outra. A ética está sempre ligada ao "cuidado" com o outro, respeitando da maneira como ele é, sem aliená-lo e instrumentalizá-lo. Por fim, descrevemos alguns argumentos sobre a evolução da moral na história do Ocidente, a começar pela medieval, moderna e contemporânea. A primeira segue a filosofia cristã, a segunda, a dimensão da técnica e da ciência, e, por fim, a dimensão da moral pós-moderna fundamentada no relativismo, no fim do esforço e da disciplina, no hiperindividualismo e no egocentrismo.

Palavras-chave: Ética, Moral, Pós-modernidade, Contemporaneidade.

Abstract: This article deals with the dimension of ethics and morality in contemporary times. By ethics we understand principles, values, habits and customs that were created by man so that he could live in society. On the other hand, morality is linked to more particular actions, permeated by a strong religious appeal. We will see that ethics is always relative and changes according to time, space and culture. What may be unethical for one community may be well-accepted for another. Ethics is always linked to the "care" with each other, respecting the way it is, without alienating it and instrumentalize it. Finally, we describe some arguments about the evolution of morality in the history of the West, starting with medieval, modern and contemporary. The first follows the Christian philosophy, the second, the size of technology and science, and, finally,

\footnotetext{
* Professor do departamento de Ciências Sociais da UFSM. E-mail: dcremoisp@yahoo.com.br.
} 
Campos Neutrais - Revista Latino-Americana de Relações Internacionais Vol. 1 No 1, Janeiro - Abril de 2019

the size of postmodern moral relativism founded at the end of the effort and discipline, hyper and egocentricity.

Keywords: Ethics, Morals, Postmodernity, Contemporaneity

\section{Introdução}

Gostaria de iniciar este artigo tratando da ética, já que ela está relacionada à natureza humana, mais precisamente ao seu modo de comportar-se, por isso esse assunto é tratado em diferentes tempos e lugares de acordo com a dimensão cultural de cada povo. Como é do conhecimento de todos, a história ocidental alcançou um patamar de reconhecimento no mundo inteiro ao começar com as poesias de Homero e Hesíodo constituindo a base da formação do povo grego. $\mathrm{O}$ ethos humano continuou sendo tratado pelos primeiros pensadores, denominados de pré-socráticos, passando pela sofística até Sócrates, Platão e Aristóteles, sendo que, para estes últimos, o tema de ethos torna-se um problema principal Bocayuva (2013).

Há certa dificuldade em traduzir a palavra "ética", mas podemos afirmar que ela é de origem grega (ethos) e, no campo filosófico, pode ser traduzida pelas ideias de "lugar", "residência", "ambiente" e, por extensão, também como "caráter", "distinção", "modo" e "natureza" Costa (2013). A ética será tratada como fundamento para uma vida boa. Quanto mais éticas forem as nossas ações, mais sentido damos à nossa existência. Em um primeiro momento vamos expor os diferentes entendimentos da palavra ética e as suas mudanças históricas e culturais, para, logo após, tratar da ética como cuidado. Por fim vamos discutir aspectos ligados à ética e à moral na contemporaneidade. ${ }^{1}$

\section{Diferentes entendimentos}

Definir a palavra "ética" não é uma empreitada fácil, pois ela pode ter vários significados. Pela etimologia, como já dito, vem do grego (ethos), que significa "morada do homem" Lima Vaz (2000, p. 12). Para os gregos, a morada era a cidade, que eles chamavam de pólis (comunidade). Desse modo, a ética

1 Sobre o termo "Contemporaneidade" conferir o trabalho de Goffman (2010). 
seria o "lugar onde os homens habitam" - sua própria casa, seu hábitat, lugar da residência familiar, assim como a maneira de nele estar, a maneira de se relacionar consigo mesmo e com os outros Savater (2000). A ética estaria ligada aos hábitos e aos costumes de um indivíduo ou da sociedade e de como ela se comporta em um determinado lugar ou em um determinado período histórico. Pode-se definir a ética, então, como uma reflexão sobre regras, leis, modo de ser, caráter, costumes e valores de uma sociedade Valls (2008).

Já para os romanos a palavra ética era denominada de ethiké - em latim, ou seja, mos, os modos e costumes, no plural, "mores" para exprimir "o que é relativo aos costumes”. Assim, como se percebe, a ética e a moral eram conceitos muito próximos entre os gregos e romanos.

Para a compreensão mais contemporânea, a ética pode ser entendida de maneira um pouco diferente. Ética seriam os princípios universais, que, portanto, aplicam-se a todos, de forma mais imparcial, ou seja, baseiam-se no preceito de que os indivíduos ou os seus interesses devem receber igual respeito. Em seu sentido mais amplo, argumentam Outhwaite e Botomore (1996, p. 278), "a ética refere-se à avaliação normativa das ações e do caráter de indivíduos e grupos sociais”. A ética é a reflexão sobre a melhor forma de viver e conviver, ou seja, são princípios universais que regem a sociedade. Já a moral, como veremos mais à frente, estaria mais ligada a decisões pessoais que tomamos. Sendo assim, a ética é sempre um olhar vigilante sobre a moral. A ética é a avaliação normativa das ações e do caráter de indivíduos e dos grupos sociais. Como diz Roger Pol-Droit (2012), "a ética faz com que o homem se pergunte qual a melhor maneira de agir"; e mais: "[...] a ética é, antes de tudo, o conjunto de reflexões ligadas a questões do gênero - O que devo fazer? Como devo me comportar?"

A ética é, assim, um conceito mais aberto; está relacionada ao homem e a suas escolhas. Como diz Sartre (1978, p. 220): "escolhendo-me, escolho o homem". Isto é, somente o homem tem a possibilidade da escolha, de deliberar, de decidir que caminho seguir, optar por agir de maneira correta ou errada. Nesse sentido, a ética é uma criação genuinamente humana, dado que as formigas, as abelhas ou nenhum outro animal é regido por princípios éticos, 
Campos Neutrais - Revista Latino-Americana de Relações Internacionais Vol. 1 No 1, Janeiro - Abril de 2019

nenhum deles tem liberdade e nem um único deles é capaz de tomar decisões por contra própria.

A ética também é sempre relativa, porquanto muda com o tempo (época), muda de acordo com a cultura e com crenças de diferentes grupos sociais ou civilizações. O certo e o errado diferem de cultura para cultura. Dizem Rachels e Rachels (2013, p. 26): “[...] culturas diferentes têm códigos diferentes. O que é pensado como correto por um grupo pode horrorizar os membros de um outro grupo e vice-versa". Ou, como lemos em Valls (2008, p. 13): "os costumes variam com o tempo e os valores também". Passamos a citar alguns exemplos para demonstrar a relatividade da ética.

Para nós, ocidentais, a poligamia - palavra originada do grego, significando "muitos matrimônios" - não é aceita legal nem moralmente. Diferentemente, não obstante a poligamia é uma prática comum em mais de 50 países em todo o mundo, como na África e no Oriente Médio. A poligamia é comum também em países muçulmanos, com a ressalva de que os homens poligâmicos tenham posses suficientes para sustentar as suas esposas. Ter várias mulheres é sinal de status e de poder.

Os povos nativos do Alaska, Norte do Canadá, da Groelândia e do Nordeste da Sibéria, que eram denominados de esquimós até meados do século XX, tinham uma cultura bastante volátil em relação ao casamento. Homens geralmente tinham mais de uma esposa, da mesma forma que compartilhavam suas esposas com os convidados, emprestando-as durante a noite como um sinal de hospitalidade. A prática do infanticídio também era comum entre os esquimós, diferente da nossa compreensão atual sobre o casamento e sobre a criação dos filhos. Mas, como argumentam Rachels e Rachels (2013, p. 27), "se assumimos que nossas ideias éticas serão partilhadas por todas as culturas, nós somos ingênuos, meramente."

Até há pouco tempo, fumar em espaço público era comum. Quem não se lembra dos tempos de faculdade, quando nossos professores fumavam tranquilamente enquanto ministravam suas aulas, sem se importar com a inalação da fumaça por seus alunos? Em restaurantes, ônibus, teatros, cinemas e até em biblioteca era comum as pessoas fumarem sem se preocupar com o 
incômodo aos não fumantes. Atualmente isso está muito diferente, pois há espaços reservados para fumantes e não fumantes. Além da proibição de fumar em lugares públicos, há um consenso de que tal prática é refutada por todos.

Outro exemplo de mudança de comportamento diz respeito às uniões homoafetivas. Até há pouco tempo era muito difícil ver duas pessoas do mesmo sexo de mãos dadas nas ruas ou manifestando alguma forma de afeto. Nos nossos dias, apesar de práticas homofóbicas, há uma aceitação maior da sociedade em relação às pessoas gays. Houve avanços nas leis garantindo direitos substanciais de casais do mesmo sexo. Como dizem Rachels e Rachels (2013, p. 56), "dizer que os homossexuais não devem agir de acordo com seus desejos é, portanto, condená-los a uma vida frustrada. Homossexuais e heterossexuais descobrem quem são após eles terem uma certa idade, ninguém decide por qual sexo quer ter atração".

O filósofo brasileiro Mario Sérgio Cortella (2013) cita ainda o uso do cinto de segurança como mudança comportamental. Até poucos anos o uso desse instrumento era muito negligenciado. Hoje não mais. Além da obrigatoriedade, o uso do cinto de segurança passou a ser incorporado na nossa prática quotidiana ao dirigir. No início, as pessoas relutavam em usá-lo. Era comum as pessoas comprarem a camiseta do time de futebol do Vasco da Gama ou da Ponte Preta, com a lista preta transversal, no intuito de enganar os guardas de trânsito, fingindo estarem usando o cinto de segurança, brinca Cortella (2013). Hoje, além de salvar vidas, quase que inconscientemente nós o colocamos quando sentamos para dirigir nosso carro. Se porventura esquecemos, somos lembrados e cobrados por nossos filhos, que já adotaram a ideia.

Em suma, a ética é aquilo que orienta a capacidade de o homem poder decidir, julgar e avaliar com autonomia. Para isso, pressupõe a presença da liberdade. Ou seja, como já defendia o filósofo Kant (2007), a ética deve ser baseada em direitos em que a pessoa deva ser tratada como fim em si mesmo e nunca como meio, ou seja, jamais devo instrumentalizar o meu próximo tendo em vista o meu "sucesso" pessoal: "age de tal maneira que uses a humanidade, tanto na tua pessoa como na pessoa de qualquer outro, sempre e 
Campos Neutrais - Revista Latino-Americana de Relações Internacionais Vol. 1 No 1, Janeiro - Abril de 2019

simultaneamente como fim e nunca simplesmente como meio" 2 (KANT, 2007, p. 69).

\section{Ética é cuidado}

Os princípios éticos levam em conta e respeitam a alteridade do outro, o que significa ver o outro como ele realmente é, não aliená-lo, não vê-lo como estranho. A alienação (aliens) ética é a negação do alter (outro), desconsiderar o outro enquanto pessoa. Um exemplo que chegou até os meios de comunicação foi a experiência da pesquisa de psicologia social de Fernando Braga da Costa que analisou a profissão dos garis como "pessoas invisíveis". Depois de vestir o uniforme de gari e varrer as ruas da própria universidade, ninguém mais o reconheceu, nem seus colegas, nem seus professores. Conclusão: o uniforme torna as pessoas invisíveis. A negação da alteridade do outro também pode ser encontrada no primeiro livro bíblico, o Gênesis. Na visão bíblica, Deus pergunta a Caim: “Onde está o teu irmão?” E Caim responde: "Por ventura serei eu o guarda do meu irmão?" Sendo assim, a ética é, antes de tudo, o reconhecimento do “outro" enquanto "outro”, não a sua negação.

O escritor português José Saramago, em seu livro Ensaio sobre a Cegueira, tem uma frase logo no início do livro que é central no debate sobre a alteridade do outro: "Se podes olhar, vê; se podes ver, repara". O que acontece é que muitas vezes passamos e não olhamos; se olhamos, não vemos; se vemos, não reparamos. O que é reparar? Reparar é olhar com cuidado, estar atento aos mínimos detalhes da vida que nos cercam: o orvalho na flor, o pôr do sol, a brisa que toca o meu rosto, o sorriso de uma criança, as rugas da face envelhecida de um ancião ou de uma anciã. O ruim é quando colocamos a vida no "automático". Ou seja, quando agimos como seres autômatos, mecanicamente, sem dar sentido às coisas e às pessoas. O escritor uruguaio Eduardo Galeano, que nos deixou há pouco tempo, só tinha um sentimento ao deixar este mundo: "Triste é morrer e

2A ética baseada em direito (lei) é defendida pela teoria contratualista e por Immanuel Kant, filósofo iluminista do século XVIII. 
não mais contemplar o crepúsculo". Para ele, o fim de cada tarde era dotado de significados que o faziam feliz.

Também me lembro com carinho e com certa nostalgia da minha infância no interior. 3 Hoje tenho certeza de que foram os momentos mais felizes da minha vida. Saudades de tudo aquilo que eu tinha e não tenho mais: o afeto da mãe, a figura do pai, o carinho dos irmãos. Saí muito jovem de casa para estudar, no entanto, no final de cada ano, fins de novembro, entrava em férias e voltava para o lar para ajudar os pais nas lidas da agricultura. Minha mãe sempre me recebia com os braços abertos, lágrimas de saudades escorriam no rosto de ambos. Ela sempre me esperava com o bolo de laranja preferido e o pudim de forma de que eu tanto gostava. A casa estava limpa e o cheiro da cera - Cera Cachopa - ainda está presente em mim. Minha mãe dizia: "Entre, filho, só não repare que a casa não está muito organizada”. Mas era exatamente o contrário. O que ela queria na verdade é que eu percebesse que a casa estava bem limpinha, pronta para receber o filho. A ética passa um pouco por aí, na preocupação e pelo cuidado do outro das coisas e do outro.

Seguindo na mesma ideia, o escritor Fernando Savater (2012), em seu livro "Ética para meu Filho", também se lembrou de uma importante cena do cinema para ilustrar o caráter da sociabilidade humana e do tempo de infância. Recordou ele a cena inicial do filme "Cidadão Kane", dirigido e interpretado por Orson Welles. Como todos sabem, Welles produziu o filme Cidadão Kane, mas a produção havia sido supostamente atribuída ao jornalista William Randolph Hearst, embora Welles o negasse. No filme, Welles interpreta o personagem Kane, que era um importante magnata das comunicações e multimilionário americano que alcançou uma influência política jamais vista até então. Vivia sem nenhum tipo de escrúpulo em Xanadu, conseguia o que queria graças à instrumentalização das pessoas que viviam ao seu redor. A sua ganância sempre falou mais alto. No final da vida, em seus momentos derradeiros, Kane

3 A palavra "nostalgia" é composta por duas palavras gregas: nostós (retorno, regresso a casa) e algos (dor, sofrimento). A dor que pede o retorno de uma alegria passada (ALVES, 2012, p. 162). Isto é, saudade da casa paterna, dos irmãos, dos brinquedos, dos campos verdes e das colinas. Cf. também Cortella e La Taille (2013, p. 41). 
Campos Neutrais - Revista Latino-Americana de Relações Internacionais Vol. 1 No 1, Janeiro - Abril de 2019

perambula solitário na grandiosa sala de seu palácio cheia de espelhos que o refletem em centenas de imagens, mas na verdade, só existe o solitário Kane.

Kane em agonia murmura uma palavra de que ninguém sabe ao certo o significado: "Rosebud"! Mais tarde se descobre que "Rosebud" é uma palavra escrita em num trenó com a qual Kane brincava quando criança. Essa mensagem é marcante, uma vez que talvez recorde o único tempo em que esteve rodeado de pessoas com quem tivesse os afetos mais importantes de sua vida, pessoas que amava e que o amavam. Pode-se aprender dessa cena que riqueza, poder e prestígio não puderam comprar-lhe nada melhor do que aquela lembrança infantil. O trenó significava a doce lembrança das relações humanas, o que realmente interessa aos homens. Muitas vezes invejamos a riqueza, o prestígio, a fama e o poder alheio e esquecemos que talvez isso não sirva para quase nada, ou não serve para aquilo que realmente interessa para uma vida virtuosa e feliz.

No corre-corre da vida pós-moderna, onde tudo é regido pelo "fast", esquecemos os pequenos detalhes que fazem a diferença. Passamos apenas pela vida e não vivemos. Devemos, sim, exercitar a arte do "reparar", de vislumbrar o significado das coisas, isto é, refletir. Ou, como um homem muito sábio disse certa vez: "Gnosis, a perfeita sabedoria e iluminação, é se surpreender com todas as coisas". A visão pragmática sobre as coisas da vida acaba fazendo com que não captemos o verdadeiro sentido delas, pois a importância das coisas acaba ligada ao seu preço, e não ao verdadeiro significado que as constitui. Eduardo Galeano sintetiza tal ideia errônea dos tempos atuais com a seguinte frase: "No mundo de hoje, tudo o que não tem preço também não tem valor”.

\section{A moral nossa de cada dia}

Como vimos, a ética estuda as relações morais. A ética é o fundamento, o princípio e é um conceito universal, por exemplo: "não pegar o que não me pertence”. Já a moral é a prática e é mais relativa, por exemplo: "se eu roubo ou não”. A ética é a reflexão crítica sobre os valores presentes nas ações entre as pessoas na sociedade. A moral coloca-se, assim, enquanto preceitos que orientam a nossa vida em sociedade. As minhas ações devem ser norteadas pela moral, 
porque é para o nosso bem. A moral pode ser demonstrada a partir da frase: "O que é que os outros vão dizer!?” É certo que devemos levar a ética e a moral em consideração, considerando que não existimos sem a presença e a relação com os outros.

Como vimos antes, a palavra "moral" veio do latim (moralis), que significa a atitude de um indivíduo em relação às normas. Assim como a ética é a reflexão filosófica sobre a melhor maneira de viver, a moral está ligada à ação, é sempre uma reflexão em primeira pessoa: uma reflexão consigo mesmo, o que eu escolho para mim, ou você pensando por você mesmo. Por outro lado, o moralismo é quando eu julgo a ação de um terceiro. O moralizador é aquele que se ocupa com a moral do vizinho, ou seja, o moralismo é a avaliação do outro.

Se a ética ensina a "não roubar" ou "não pegar o que não me pertence", a moral é uma decisão pessoal sobre as práticas do cotidiano, por exemplo: “quando encontro uma carteira com dinheiro, devolvo ou não devolvo?” Mesmo assim há dilemas, como saber se uma ação pode ser boa ou condenável. Segundo o filósofo André Comte-Sponville (2002, p. 22), basta perguntar a si mesmo o que se passaria se toda a humanidade se comportasse como você: "Se todos mentissem, se todos matassem, se todos torturassem, como a humanidade viveria?” Para Comte-Sponville (2002), a moral cristã talvez seja a que mais se aproxime da prerrogativa anterior: "Não façais ao outro o que não gostaríeis que o outro vos fizesse".

Nesse sentido, a moral vai além da frase proferida pela personagem de Dostoiévski em que diz: "Se Deus não existisse, tudo seria permitido". Não, nem tudo é permitido, mesmo sendo descrente. A moral independe de um credo religioso, porque vai além. Seria medíocre o homem que só fizesse o bem pelo temor do castigo eterno ou, ao contrário, só fizesse o bem à espera de uma recompensa eterna. Seria apenas uma questão de egoísmo e prudência. Diferentemente pensa o filósofo Kant ao afirmar que uma ação moralmente boa é aquela que é feita sem esperar nada em troca. Assim, mesmo que Deus não exista, mesmo que não exista nada depois da morte, isso não nos dispensa dos nossos fazeres e deveres, ou seja, de agir humanamente. Então, em outras 
Campos Neutrais - Revista Latino-Americana de Relações Internacionais Vol. 1 No 1, Janeiro - Abril de 2019

palavras, o nosso único dever é ser humano (COMTE-SPONVILLE, 2002, p. 1726).

A moral nos fará sempre nos perguntar: Posso ou não posso? Viver moralmente é agir de tal forma honesta, digna e justa, como se estivéssemos vivendo de forma invisível, como veremos agora, na história contada por Platão (1999) sobre o anel de Giges, um bom exemplo do agir moral.

Conta Platão:

Ele [Giges] um pastor que servia ao então soberano da Lídia. Devido a uma grande tempestade e tremor de terra, rasgou-se o solo e abriu-se uma fenda no local onde ele apascentava o rebanho. Admirado ao ver tal coisa, desceu por lá e contemplou, entre outras maravilhas, um cavalo de bronze, oco, com umas aberturas, espreitando através das quais viu lá dentro um cadáver, aparentemente maior do que um homem, e que não tinha mais nada senão um anel de ouro na mão. Arrancou-lhe o anel do dedo e saiu. Ora, como os pastores se tivessem reunido, da maneira habitual, a fim de comunicarem ao rei, todos os meses, o que dizia respeito aos rebanhos, Giges foi lá também, com o seu anel. Estando ele, pois, sentado no meio dos outros, deu por acaso uma volta ao engaste do anel para dentro, em direção à parte interna da mão, e, ao fazer isso, tornou-se invisível para os que estavam ao lado, os quais falavam dele como se se tivesse ido embora. Admirado, passou de novo a mão pelo anel e virou para fora o engaste. Assim que o fez, tornou-se visível. Tendo observado esses fatos, experimentou a ver se o anel tinha aquele poder, e verificou que, se voltasse o engaste para dentro, se tornava invisível; se o voltasse para fora, ficava visível. Assim, senhor de si, logo tratou de ser um dos delegados que iam junto do rei. Uma vez lá chegado, seduziu a mulher do soberano e, com o auxílio dela, atacou-o e matou-o, e assim se assenhoreou do poder (PLATÃO, 1999).

Imaginemos que, assim como Giges, de uma hora para outra pudéssemos ficar invisíveis: Como agiríamos? Faríamos o bem ou o mal? Buscaríamos o prazer, a riqueza e os interesses egoístas? Com o poder da invisibilidade, continuaria eu a respeitar o semelhante, a sua propriedade, a sua intimidade e a sua liberdade? No agir moral, sim. Mesmo invisível, eu continuaria obrigado e proibido, não por interesse, mas por dever, a não fazer o mal. Isso é moral. A moral é aquilo que exiges de ti, não em função do olhar de outros, por ser vigiado 
por câmeras ou desta ou daquela ameaça exterior (lei ou prisão), mas em nome de uma certa concepção do bem e do mal, do dever e do interdito, do admissível e do inadmissível, enfim, da humanidade e de ti. Nas palavras de Comte-Sponville (2002):

[...] a moral é um conjunto de coisas a que um indivíduo se obriga ou que proíbe a si mesmo, não para aumentar a sua felicidade ou o seu bem-estar, o que não passaria de egoísmo, mas para levar em conta os interesses ou os direitos do outro, para não ser um malvado, para permanecer fiel a uma certa ideia de humanidade e de si (COMTE-SPONVILLE, 2002).

A moral então está ligada à nossa forma de agir independentemente do olhar do outro. Enfim, a moral, ainda de acordo com Comte-Sponville (2002; 2009), é uma lei que imponho a mim mesmo ou, como diz Taylor (2011, p. 35), “a moralidade tem, em certo sentido, uma voz interna".

Muitos são os exemplos que podem ser citados para demonstrar o agir moral. Por exemplo, se o professor está aplicando uma prova aos alunos sem consulta, o professor sai da sala de aula por um instante, o aluno tem um resumo completo sob a escrivaninha. É nesse momento que ele se pergunta: "Colo ou não colo? " Colar ou não é uma questão moral. Às vezes, como professor, solicito, no final de cada aula, uma lista de presença dos alunos, mas antes de passar a lista já contei o número total dos alunos presentes em sala de aula, 24, por exemplo. No fim, por incrível que pareça, surgem 27 nomes na lista. Bom, como o espiritismo anda em alta nos nossos tempos, penso que algum espírito baixou por ali e assinou a lista de presença. Assinar pelo outro também é um gesto de falta de moral.

Por falar em moral, lembro uma bela história contada pelo escritor Fernando Savater (2002), que trata sobre a incoerência entre o modo de cada um ser e viver. Trata-se do falso moralismo que cada um tende a desenvolver em muitas situações da vida. Conta a história da falsa moralista puritana que numa tarde de verão ligou para o delegado de polícia reclamando que, em frente à sua casa, alguns jovens brincavam na rua seminus divertindo-se num alegre banho de mangueira. O delegado e sua guarnição, atendendo a moralista, vai até o local e pede para que os jovens se afastem para não perturbam o sossego da mulher. Os 
meninos atendem o pedido e passam a se divertir noutro quarteirão. Passada meia hora a mesma mulher liga novamente ao delegado reclamando que os meninos continuam com as brincadeiras. Novamente o delegado se dirige aos jovens pedindo que eles se divirtam em outro local, ainda mais longe. Os meninos obedecem novamente. Todavia, por incrível que pareça, a mesma mulher "puritana" liga pela terceira vez reclamando daquelas cenas impudicas. O delegado esboçando um tom de surpresa e irritação argumenta: "Minha senhora, atendemos o seu pedido por duas vezes, afastamos os jovens para bem longe de sua casa para que não mais a importunasse..." Eis que veio a resposta da moralista: "É, mas de binóculo eu ainda consigo vê-los".

Um outro exemplo de dilema moral aconteceu comigo. Marquei com um amigo uma pescaria, lazer de que gosto muito. O combinado foi que eu iria com meu carro da minha cidade, enquanto meu amigo, com seu carro, barco e todo o equipamento, viria da sua cidade no domingo pela manhã. Nós nos encontraríamos logo cedo no lugar marcado, bem cedinho, em torno das 7 horas. $\mathrm{E}$ assim foi. Cheguei ao local, que estava deserto, e meu amigo demorava a chegar. Fui caminhando lentamente junto à margem do lago e visualizei uma corda fina amarrada em uma árvore indo diretamente para as calmas águas. Olhei por perto, não vi ninguém e fui puxando aquela corda e, para a minha surpresa, era uma grande rede com malha pequena para capturar o lambari. Nunca tinha visto tanto peixe.

Novamente olhei em volta e ninguém aparecia, nem mesmo meu amigo. Logo pensei comigo: “Achado não é roubado”, e de maneira mais rápida comecei a desmalhar os peixes, colocando em um saco, que logo já passava de cinco quilos. Rapidamente amarrei o saco de peixes com a rede e guardei em meu carro, ainda olhei ao redor para ver se não estava sendo vigiado. Nisso chegou meu amigo, e eu de imediato lhe conto a proeza do meu achado, bem faceiro. Estamos prestes a embarcar para subir mais para o norte para a nossa pesca e ouço um barulho de automóvel e eis que chega uma família de ribeirinhos. O senhor recém-chegado vai em direção da rede e exclama: "Puxa vida, alguém roubou a minha rede... Tinha deixado ontem à tarde ela no lago e agora se foi...” E eu fingi não ouvir aquela exclamação. 
Tratei de entrar no barco e sumir dali, no entanto aquela ideia não me saía da cabeça durante todo o dia de pesca: Devolvo ou não devolvo os peixes e a rede? Ora pensava em devolver, ora em não devolver. Afinal, eu achei, tirei os peixes, e eles estavam na caixa de isopor do meu carro, bem fresquinhos. Ocorreu então que, quando retornei à margem, aquela família ainda estava lá acampada e eu não tive mais dúvidas. Tomei a decisão: fui ao encontro do senhor e lhe disse: "Cheguei pela manhã e encontrei esta rede e me parece que ela pertence ao senhor. Por isso estou lhe devolvendo." O senhor ficou feliz por ter reencontrado a sua rede (com os peixes) e me agradeceu pelo gesto. Bom, de certa forma fui embora da pescaria sem os peixes, mas com a consciência tranquila e feliz por ter agido daquela forma, pois, como diz Spinoza: "Fazer o bem é estar sempre feliz".

Enfim, eis pequenos exemplos para demonstrar que a moral é sempre uma opção, já que só eu sei o que eu devo fazer. Ninguém decide em meu lugar. A ética e a moral estão ligadas a valores que são considerados nobres, valores que o homem deve colocar sempre em um patamar elevado, visto que eles fazem com que ele se humanize cada vez mais em relação a outro homem.

\section{A moral na Contemporaneidade}

A moral cristã surge nas regiões periféricas do grande Império Romano. O cristianismo então era uma religião de escravos que foram perseguidos e torturados nos primeiros séculos da nossa era. No ano de 313 o imperador romano Constantino concedeu liberdade condicional aos cristãos. Mais tarde, no final do século IV, em 391, o imperador Teodósio proibiu finalmente os cultos pagãos e adotou o credo cristão como religião oficial do Ocidente (BARRACLOUGH, 1972, p. 22).

Santo Agostinho foi o principal responsável pela defesa teórica e prática do cristianismo e da Igreja. Escreveu a obra "as Confissões", onde inclusive comenta sobre a filosofia do estoicismo. O amor, diz ele, é eterno, porque meus amados vão ressuscitar e vou ficar com eles para sempre. A eternidade está garantida, e o apego também. Contam os historiadores que, no enterro da própria mãe, Agostinho não derramou nenhuma lágrima: "Por que estaria triste, pois nos 
Campos Neutrais - Revista Latino-Americana de Relações Internacionais Vol. 1 No 1, Janeiro - Abril de 2019

encontraremos definitivamente no céu, eternamente no paraíso, nós que nos amamos tanto”. Segundo a filosofia cristã, a salvação já está garantida; todos vão ressuscitar de corpo e alma junto com seus entes queridos, de acordo com seus méritos ou não. Mais tarde o filósofo Pascal vai se questionar: Acreditar ou não acreditar? Eis a sua aposta: "É preferível passar por bobo neste mundo, porque, se der certo, ganho a eternidade".

Dessa forma, o cristianismo nos promete tudo: a eternidade. O quarto evangelista - São João - também conhecia a filosofia estoica: "No princípio era o verbo (logos) e o verbo estava com Deus. Tudo foi feito por meio dele e sem ele nada foi feito. E o verbo se fez carne e habitou entre nós”. Há uma diferenciação básica entre a filosofia e a religião. Enquanto a filosofia é pensar por si mesmo, a religião é confiar em um "outro". Outra diferenciação: enquanto a pólis grega se baseava na escravidão, o cristianismo pregava a igualdade. Em relação aos judeus que pregavam a Lei, os cristãos pregavam a Consciência. Da mesma forma em relação aos estoicos: estes pregavam o homem como fragmento cósmico inconsciente, já o cristianismo prega a imortalidade pessoal, a ressurreição dos corpos.

Historicamente a moral apresenta três eras com características próprias. A primeira fase da moral, como vimos, é a era teológica da moral; a segunda é a moral moderna, chamada de laica moralista; e a terceira é chamada de pósmoralista (LIPOVETSKY, 2004).

A primeira fase da moral, assunto tratado um pouco antes, ampara-se na tradição judaico-cristã. Mais especificamente podemos encontrá-la no Velho Testamento, quando Moisés recebe as Tábuas da Lei. A moral teológica era inseparável dos mandamentos divinos que foram recebidas por revelação. A Bíblia era o fundamento da verdadeira moral. Essa moral afirmava que fora da Igreja e de seus ensinamentos não havia virtudes. Com o cristianismo, Jesus, no chamado Sermão da Montanha, centraliza as atenções para os valores da pessoa. A ideia é que o amor (ágape) possa elevar o homem de sua condição puramente humana para uma condição de valores transcendentais. O homem com princípios morais é um homem que teme a Deus e espera nele a salvação de sua alma. São Paulo apóstolo foi o grande incentivador das ideias cristãs. Mais tarde, Santo 
Agostinho e São Tomás de Aquino farão uma defesa racional da fé por meio das duas escolas filosóficas: a Patrística e a Escolástica, respectivamente. Em síntese, esse período da moral teológica é considerado o mais longo do Ocidente, pois começa na tradição judaica, desde o Antigo Testamento, e segue até o início do século XVIII.

A segunda fase da história da moral começa no início do século XVIII e termina no início do século XX. É qualificada como moral laica moralista. De forte inspiração iluminista, a moral moderna procura se emancipar da moral religiosa da Igreja. Os fundamentos da moralidade laica se fundamentam nos princípios da racionalidade, também chamada de moral natural, que estariam presentes em todos os homens. Kant e Voltaire são os defensores de uma ética enraizada na natureza humana. Kant propõe que o conceito ético seja extraído do fato de que cada um deve se comportar de acordo com os princípios universais, conhecido como princípio categórico (obrigação - não dependente de quaisquer desejos da pessoa). A lei máxima do imperativo categórico kantiano é: “Age apenas segundo uma máxima tal que possas ao mesmo tempo querer que ela se torne lei universal"4.

Aos poucos os valores religiosos, como jejum, caridade, penitências, rezas e peregrinações, são substituídos pela obediência à lei moral. A secularização encontrará respaldo nos direitos naturais, na razão e no humanismo ético. Nesse momento prescinde-se da crença e da fé na vida do homem, visto que este pode viver de forma moral e sem ter religião e mesmo assim não sofrerá nenhuma punição ou castigo. Isso equivale a dizer que é possível um homem ser ateu e ser moral ao mesmo tempo. Surge a religião moderna do dever, o culto laico da abnegação e da entrega ilimitada a serviço da família, da pátria e da história. Mantém-se, contudo, como afirma Lipovetsky (2004), "a retórica anterior do dever rigorista, sacrifical, absoluto".

A terceira fase da moral é chamada de "pós-moralista". Essa nova moral rompe drasticamente com a moral moderna do século XVII e XVIII. A moral pós-

\footnotetext{
4 Em termos éticos, o imperativo categórico kantiano deixa essa mensagem: "age sempre de tal forma que trates a humanidade na tua própria pessoa e na pessoa de outrem, nunca como um meio, mas sempre também como um fim em si”.
} 
moralista exalta mais os desejos, o ego, a felicidade e o bem-estar individual do que o ideal de abnegação. De certa forma, ficou abandonada a moral do dever sacrifical, pois hoje o que importa é o sucesso pessoal, são os direitos dos indivíduos, e não os seus deveres. O que impera hoje é o relativismo moral, sendo que cada um pode fazer o que bem entender: "Nada está errado". O que importa é o bem-estar pessoal, numa realidade em que os "deveres" foram relativizados, vivendo-se uma moral mais de cunho emocional. O dever sacrificial não é mais exaltado na escola, nem nos livros, nem na esfera pública. Antes a moral era austera e autoritária, vinda geralmente dos discursos disciplinadores do clero.

Vive-se na sociedade pós-moralista o oposto da teoria de Durkheim, que pregava que o espírito de disciplina era a essência da moral. De certa forma a mídia assume o lugar da educação moral anterior. Ela fixa as prioridades. Vive-se o fim da moralidade da disciplina e do esforço para uma moralidade sem obrigações nem sanções - uma moral emocional, uma moral interpessoal, adaptada aos novos valores individualistas, como dizia Sartre (1978), em que cada um passou a ter de determinar-se, de inventar a sua moral. Cada um tem uma posição sobre o aborto, sobre o consumo de drogas, sobre a pena de morte, sobre eutanásia, sobre casamento homossexual, sobre fertilização com ajuda médica, tudo isso configurando a pluralidade de morais.

A moral no mundo contemporâneo é uma moral que rompe com o modelo harmônico dos gregos, medievais e modernos. Trata-se de uma tripla ruptura.

Quanto a essas rupturas, segundo a primeira, não se pode mais pensar à moda dos gregos, nem dos medievais, nem dos modernos. Por isso aceita a condição pós-moderna. A moral pós-moderna rompeu com a visão dos gregos do período clássico. Os gregos partiam da ideia do universo cósmico ordenado e finito. Todas as coisas teriam um lugar natural, com finalidades próprias. Para viver bem dever-se-ia viver no lugar certo, fazendo a coisa certa, "achar o seu lugar natural" para se realizar e ser feliz, o que eles chamavam de "eudaimonia": uma concepção de que a felicidade é a finalidade da vida - vida soberana, vida que não precisa de outra para se justificar. A concepção grega era a de que é preciso achar o nosso "lugar natural" no cosmos para sermos felizes. Nos nossos dias não podemos pensar assim, dado que a ciência moderna desconstruiu essa 
concepção organizada e harmônica dos gregos. O universo não é finito. O todo não é finito nem organizado. O universo é caótico, não tem sentido nem direção, não há um lugar, mas diferentes modos e compreensões do universo.

Em segundo lugar, a moral pós-moderna rompeu também com os medievais, que tinha seus fundamentos na crença em Deus e na instituição da Igreja. Deus era a salvação e esse ser transcendente respondia aos meus anseios. No lugar do universo cósmico e organizado, segundo a compreensão grega, agora Deus criava e organizava tudo. $\mathrm{O}$ universo enquanto mundo pode não ser mais organizado, mas temos Deus que nos deu uma missão para que possamos nos encontrar na vida boa.

Por fim, a moral pós-moderna rompeu com a Modernidade - uma terceira ruptura. Nesse momento histórico o homem tomou o outro como referência, a vida em sociedade. Maquiavel, Bacon, Newton, Descartes e Locke são os fundadores do pensamento racional moderno na defesa dos direitos naturais dos cidadãos.

Mesmo assim, no século XIX temos a incisiva crítica realizada pelos chamados filósofos "desconstrutores", em especial Nietzsche, Marx e Freud. O filósofo Nietzsche, o filósofo do "martelo", foi contrário à moral cristã. A moral cristã, para ele, é geradora de sentimento de culpa e de ressentimento, fundada na aceitação do sofrimento, da renúncia, do altruísmo, da piedade, típica da moral dos fracos. Para Nietzsche, é preciso recuperar o sentimento de potência, a alegria de viver, a capacidade de invenção. O filósofo critica também os fundamentos éticos, desde Platão até o cristianismo, bem como o caráter moralista da civilização ocidental.

Para Marx, a filosofia deve estar centrada na coletividade. Seu pensamento teve um caráter mais político do que ético. Para o marxismo, a ética decorre da política. Marx procura desmitificar a moral e a ideologia, pois para ele os fundamentos éticos são vistos como instrumento de dominação. A análise éticopolítica para ele tem a função de desvelar o processo histórico de ascensão e consolidação da classe burguesa como dominante. A ética é tida como um produto histórico que regula historicamente as relações humanas e as justifica essas relações em cada época histórica. 
Já Freud, o terceiro “desconstrutor”, os preceitos morais são elementos superestruturais que visam impedir a expansão dos impulsos primários recalcados no inconsciente. Para ele, o homem vive permanentemente sob a censura da civilização e a civilização é constitutivamente repressão.

Uma conquista da Modernidade foi o nascimento da concepção do homem como indivíduo. Por meio das revoluções liberais surge o entendimento de que o homem é dotado de direitos naturais, direitos como a preservação da vida, como a propriedade e a liberdade. Não obstante o que prevalece na sociedade atual não é mais a individualidade, e sim o hiperindividualismo, que é uma característica doentia da pessoa 5 . Lembro-me do trecho de uma música de uma banda de rock brasileiro dos anos 1980 - a Ultraje a Rigor - que ilustra bem esse argumento: "Eu me amo, eu me adoro, eu não consigo viver sem mim". Da mesma forma, o individualismo, diz o filósofo Edgar Morin (2005), fortalece o egocentrismo. Egocentrismo é quando colocamos o "Eu" sobre o "Nós". O individualismo ou o egocentrismo, diz Morin (2005), inibe as potencialidades altruístas e solidárias, o que contribui para a desintegração das comunidades tradicionais. Assim, o individualismo/egocentrismo é o crescimento de uma necessidade individual de amor em que a busca da felicidade pessoal a qualquer preço transgride a ética familiar ou conjugal.

O professor Leandro Karnal (2015) ilustra bem o egocentrismo e a ausência da prática de ouvir o outro. Se uma pessoa diz "Eu estou cansada", a outra pessoa responde "Eu também". "Eu acordei às 4 da manhã!", o outro responde "Eu às 3 ". "Estou com dor cabeça" ou "Estou com um tumor maligno". Ninguém escuta ninguém, e então esta é a sociedade do monólogo (KARNAL, 2015). Caso eu precise desabafar com alguém, então vou precisar investir uma boa dose de dinheiro para os analistas. Como a sociedade pós-moderna aboliu o confessionário das igrejas, agora se paga um psicólogo. Enquanto você fala, diz Karnal, o analista responde com uma exclamação bovina "Hummmm!!!" e diz "Fale mais sobre isso".

5 A propósito, "hiperindividualismo" é um conceito desenvolvido por Gilles Lipovetsky (2004). 
$\mathrm{O}$ individualismo conduz ao niilismo, aniquilando as relações intersubjetivas e gerando uma crise do capital social. Por capital social entendemos: "[...] relações entre indivíduos e redes sociais com normas de reciprocidade e confiança daí emergentes”. Quanto maior for o individualismo menor será a virtude cívica. De certa forma abolimos a vida coletiva e social para viver em torno de nós mesmos. ${ }^{6}$ Vivemos aquilo que Gilles Lipovetsky (2004) chama de desabrochar e "absolutização do Eu".

Ao mesmo tempo em que impera o individualismo social, percebe-se o nascimento do neotribalismo. São grupos religiosos, esportivos, hedonistas, musicais e tecnológicos que se aproximam em prol de um objetivo comum. Tratase apenas de redes de amizade pontuais que se reúnem ritualisticamente com a função exclusiva de reafirmar o sentimento que um dado grupo tem de si mesmo (MAFFESOLI, 1987). Max Weber (1987) apresenta algumas características dessas "comunidades emocionais". São elas: o aspecto efêmero, a composição cambiante, a inscrição local, a ausência de uma organização e a estrutura cotidiana.

Morin (2005) defende a ideia de que vivemos, na contemporaneidade, uma crise de fundamentos. Argumenta o autor que "Deus está ausente" e que o homem moderno "matou" Deus e seus valores, dando lugar para que a razão, o progresso e a técnica assumissem seus lugares. Vive-se tipicamente o fim do superego social. O superego seria os valores sociais a serem seguidos, bem como a consciência moral que determina o que deve ser feito. $O$ sentido da responsabilidade encolheu, bem como o sentido da solidariedade enfraqueceu.

\section{Considerações finais}

Por fim, vivemos a crise das metanarrativas. Como diz Lyotard, perdemos as referências. Na Grécia Antiga, o que regia a sociedade era o cosmos (a ordem); na Idade Média (Deus); na Modernidade, a razão, a técnica, a ciência, o progresso, o iluminismo; no Mundo Contemporâneo, agora se vive o fim das

6 O fim do capital social (PUTNAM, 2000). 
Campos Neutrais - Revista Latino-Americana de Relações Internacionais Vol. 1 No 1, Janeiro - Abril de 2019

utopias coletivas como o marxismo, o socialismo, o capitalismo, a democracia7. Diz Lipovetsky (2004) que a última utopia é a dos ecologistas, embora seja um tipo particular de utopia baseada no medo, no terror. Diz-se o tempo todo que, se as coisas continuarem como estão, o planeta vai explodir. As utopias clássicas falavam de esperança. Hoje, temos, porém, muitas pequenas utopias à la carte, pessoais, particulares, singulares, sonhos de cada um: combater a miséria, preservar o patrimônio histórico, proteger a infância, melhorar o mundo, diminuir o sofrimento, ajudar os desfavorecidos.

\section{Referências}

ALVES, R. Variações sobre o prazer: Santo Agostinho, Nietzsche Marx e Babette. São Paulo: Planeta do Brasil, 2012.

BARRACLOUGH, G. Os papas na Idade Média. Lisboa: Verbo, 1972.

BARROS FILHO, Clóvis de. A vida que vale a pena ser vivida. Petrópolis: Vozes, 2010.

BOCAYUVA, I. (Org.). Ethos na antiguidade. Rio de Janeiro: Via Verita, 2013. COMTE-SPONVILLE, A. A vida humana. São Paulo: Marins Fontes, 2009. COMTE-SPONVILLE, A. Apresentações da filosofia. São Paulo: Martins Fontes, 2002.

CORTELLA, M. S.; LA TAILE, Y. Nos labirintos da moral. Campinas: Papirus 7 Mares, 2013.

COSTA, A. O ethos humano segundo Heráclito. In: BOCAYUVA, I. (Org.). Ethos na antiguidade. Rio de Janeiro: Via Verita, 2013.

DROIT, R-P. Ética - uma primeira conversa. São Paulo: Martins Fontes, 2012.

FIGAL, G. Sócrates: o filósofo. In: ERLER, M.; GRAESER, A. Filósofos da antiguidade: dos primórdios ao período clássico. Trad. Lya Luft. 1. reimpr. São Leopoldo: Unisinos, 2005.

JACOBSEN, M. H.; KRISTIANSEN, S. Labeling Gofffman. In: JACOBSEN, M. H. (org.), The contemporary Goffman. Nova York, Routledge, 2010.

KANT, I. Fundamentação da Metafísica dos Costumes. Lisboa: Edições 70, 2007.

KARNAL, L. Vazio Contemporâneo e Espiritualidade. 2015. Disponível em: <https://www.youtube.com/watch?v=tMwYxv9xf4M>. Acesso em: 1 mar. 2016.

7 Utopia, pela etimologia grega, é $u$-topos, "não lugar". O que é desejável a partir de uma sociedade mais igualitária e justa. Utopia pode ser considerada também "sonhos coletivos" empreendidos por indivíduos ou entidades sociais na busca por justiça. 
Campos Neutrais - Revista Latino-Americana de Relações Internacionais Vol. 1 No 1, Janeiro - Abril de 2019

LIMA VAZ, H. C. de. Escritos de filosofia: ética e cultura. São Paulo: Loyola, 2000.

LIPOVETSKY. G. Metamorfoses da cultura liberal. Porto Alegre: Sulina, 2004.

MARCONDES, Danilo. Textos básicos de ética: de Platão a Foucault. Rio de Janeiro: Jorge Zahar, 2007.

MORIN, E. O método 6: ética. Porto Alegre: Sulina, 2005.

OUTHWAITE, W.; BOTTOMORE, T. Dicionário do pensamento social do século XX. Rio de Janeiro: Jorge Zahar, 1996.

PLATÃO. A República. São Paulo: Nova Cultural, 1999. (Coleção Os

Pensadores).

PUTNAM, R. D. Comunidade e democracia. A experiência da Itália moderna. Rio de Janeiro: FGV, 2000.

RACHELS, J.; RACHELS, S. Os elementos da filosofia moral. Porto Alegre: AMGH, 2013.

SARTRE, J.P. O existencialismo é um humanismo. 4 ed. Tradução e notas de Vergílio Ferreira. Lisboa: Editorial Presença; Martins Fontes, 1978.

SAVATER, F. Desperta e lê. São Paulo: Martins Fontes, 2000.

SAVATER, F. Ética para meu filho. Trad. Mônica Stahel. 2. ed. São Paulo:

Planeta, 2012.

TAYLOR, C. A ética da autenticidade. São Paulo: É Realizações, 2011.

VALLS, Á. L. M. O que é ética. São Paulo: Brasiliense, 2008. (Coleção Primeiros Passos).

WARBURTON, N. Uma breve história da filosofia. Porto Alegre: L\&PM, 2013. (Coleção L\&PM Pocket). 